\title{
Banal Religiosity \\ Brazilian Athletes as New Missionaries of \\ the Neo-Pentecostal Diaspora
}

Carmen Rial (Federal University at Santa Catarina)

\begin{abstract}
This article is about the relationship between football and religion. It focuses on the recent proliferation of neo-Pentecostalism among Brazilian football players living abroad and the importance of religion in their daily lives. Serving as a civilizing device that promotes better insertion of individuals in modern institutions, neo-Pentecostalism promotes voluntary obedience, self-control, self-awareness and reflexivity, by encouraging the conscious and constant monitoring of the individual over the body and emotions. This self-discipline has a limit, and the Theology of Prosperity offers conciliation between asceticism and material consumption. Football provides religion a large stage for its preaching, allowing it to reach billions of homes. The athletes become "selfless soldiers of the Word," who demonstrate the faith globally and disseminate banal religion through the mediascape.
\end{abstract}

Keywords: Football, Religion, neo-Pentecostalism, Football Players, Banal Religion, Emigration

\section{Resumo}

O artigo trata das relações entre futebol e religião. Focaliza a expansão do neoPentecostalismo entre jogadores brasileiros no estrangeiro, a importância da religião no seus cotidianos e de como a propagam globalmente. Como um dispositivo civilizatório que promove uma melhor inserção dos indivíduos em instituições modernas, o neo Pentecostalismo promove obediência voluntaria, auto-controle, consciência de si e reflexividade, encorajando um constante e consciente monitoramento do individuo sobre seu corpo e seu espírito. Esta auto-disciplina, porem, tem limites, e a Teologia da Prosperidade permite a conciliação entre o ascetismo e o consumo material. O futebol, por seu lado, oferece a religião um palco para pregação, capaz de 
atingir bilhões simultaneamente. E soldados da Palavra, que demonstram sua fé disseminando globalmente uma religião banal.

Palavras-chave: Futebol, Religião, neo-Pentecostalismo, Jogadores de futebol, Religiao Banal, Emigração

\section{Résumé}

Cet article aborde les relations entre football et religion. Il se focalise sur la propagation du néo-pentecôtisme parmi les footballeurs brésiliens jouant à l'étranger, sur l'importance de la religion dans leur quotidien et sur la manière dont ils propagent cette dernière dans le monde. En tant que dispositif de civilisation promouvant une meilleure insertion des individus dans les institutions modernes, le néo-pentecôtisme prêche l'obéissance volontaire, l'autocontrôle, la conscience de soi et la réflexivité tout en encourageant une surveillance constante et consciente de l'individu sur son corps et son esprit. Cette autodiscipline ayant toutefois ses limites, la théologie de la prospérité permet une conciliation entre l'ascétisme et la consommation matérielle. Le football offre à la religion une scène sur laquelle la prédication peut atteindre des milliards de personne à la fois et des soldats de la Parole démontrent leur foi en disséminant dans le monde une religion banale au moyen du mediascape. Mots-clés : football, religion, néo-pentecôtisme, joueurs de football, religion banale, émigration. 


\section{Banal Religiosity \\ Brazilian Football Players as New Missionaries \\ of the Neo-Pentecostal Diaspora'}

Carmen Rial (Federal University at Santa Catarina)

Enter my house

Enter my life

Change my constitution

Heal all the wounds

Teach me to be holy

I want to love only You,

Because the Lord is my greater good,

Make a Miracle in me.

(By Regis Danese)

Among the many remarkable tourist attractions in Munich's central square, the "Brazilian" Evangelical church" ${ }^{2}$ is worthy of note. ${ }^{3}$ The quotation marks around Brazilian are justified. In fact, this is just one of hundreds of churches in the Pentecostal movement, which began in the United States and was introduced to Brazil in 1910, through the (Congregação Cristã [Christian Congregation] and the Assembléia de Deus [Assembly of God, 1911]. These gave rise to offshoots in the 1950 s such as the Igreja do Evangelho Quadrangular

1 I am grateful for the reading and suggestions made by five fellow anthropologists: Maria Amélia Dickie and Maria Regina Lisboa, who helped me avoid slipping in the religious field, Peter Fry, Miriam Grossi and Claudia Fonseca. I would also like to thank journalist and sociologist Jeffrey Hoff for the translation.

2 I use Evangelical to refer both to the historic Protestant religions as well as the Pentecostal and neoPentecostal religions. The players refer to themselves as Evangelicals and not neo-Pentecostals. Brazilian scholars refer to various Evangelical congregations, whether traditional or more recently created ones, as the "Evangelical field." In the interior of this field, they define the Pentecostal congregations as being the denominations that "share the belief of a second and immediate coming of Christ and that believes to have access, in daily life, to the gifts and charismas of the Holy Spirit" (Novaes 1998:7). Meanwhile, the neo-Pentecostals are denominations that are characterized by: an "emphasis on the war against the Devil and his entourage of fallen angels, seen mainly as the Afro-Brazilian and Spiritist cults; the preaching and promotion of the Theology of Prosperity; and greater flexibility in using visible stereotyped practices and customs of saintliness, which until recently served as symbols of conversion to Pentecostalism." (Mariano 1995:28).

3 I thank fellow anthropologist Maria Amélia Dickie for calling my attention to this monument. 
[Church of Foursquare Gospel, 1953], O Brasil para Cristo [Brazil for Christ, 1955], and in the 1960s with Deus é Amor [God is Love, 1962], which had a meteoric rise in the country, coinciding with the growth in the urban population (Fry 1978). In the mid-197os, Brazilian pastors created what became known as neo-Pentecostal congregations: Sara nossa Terra [Heal our Land, 1976], Igreja Universal do Reino do Senhor [Universal Church of the Kingdom of God, 1977], Internacional da Graça de Deus [International Grace of God, 1980], Renascer em Cristo [Reborn in Christ, 1986], Bola de Neve (Snowball) in 2000 etc. According to the the Brazilian census agency, the Brazilian Institute of Geography and Statistics (IBGE), one in every five Brazilians is now "Evangelical", in other words, 42.3 million people or $22.2 \%$ of the population (IBGE 2010).

The church that gained the most notoriety at this time was the Universal Church of the Kingdom of God, [UCKG]. In the 1980s, the Universal Church began "the internationalization of its proselytizing, thus inverting the NorthSouth direction of the missionary flow and Brazil's former condition as a destination for European and U.S. missions" (Mariano 2010). The first country in which UCKG was established outside of Brazil was the United States (1986), followed by Uruguay (1989), Portugal (1989), and Argentina (1990). The expansion abroad went hand in hand with growing emigration that reached nearly three and a half million Brazilians by the beginning of the 21st century. At the same time, other neo-Pentecostal churches (Reborn in Christ, God is Love), directed by Brazilian pastors and bishops, also went global and are now located in some 180 countries. ${ }^{4}$ They all share the belief that intimate contact with the Holy Spirit allows them access to Jesus through "possession of the Spirit." The churches share the mission of converting the world to the Evangelical faith. To accomplish this aim, they are managed as businesses and make extensive use of the mass media.

There is, however, something unique about the church in the Munich square: it was created by a football player, Jorginho, one of those most responsible for the popularity of Evangelicalism among players in the German

4 In 2000, the Universal Church of the Kingdom of God already had "franchises" in 172 countries. Its penetration is greater in Portuguese-speaking countries. In others, its temples are located within communities of Brazilian immigrants. It has confronted considerable resistance upon entering Asia (except in Japan where there are 300 thousand Brazilians) the Middle East and Africa, where non-Christian religions such as Hinduism, Buddhism, Judaism and Islam are hegemonic (Mariano 2010). 
Bundesliga. In addition to the predictable company of fellow Brazilians, including the leading striker Cacau, German players have also adhered to the Evangelical movement. Jorginho's church was initially one among many prayer groups created by players around the world - I found a similar group in Spain among the players of Celta de Vigo during ethnographic research with Brazilian football players living and working abroad.

My research draws from discussions with more than 60 Brazilian players and their entourages (families, friends, agents, secretaries, club directors and doctors) who are living or trying to live in foreign countries ${ }^{5}$. The adoption of global player recruitment strategies and the consequent growth in the transnational circulation of players is one of the central characteristics of what has been called the "second globalization of football" (Markovits and Rensmann, 2010). The first globalization began in the late $19^{\text {th }}$ century, after the 'sportization'6 of the game in England and the dissemination of of football through the British colonies. The second globalization phase (which began roughly in the 1970s) changed key aspects of football due to the growing insertion of capitalism in the sport and the associated changes stimulated by the rising interest of the media in football and the development of media technologies, such as satellite TV and the Internet. Football games are the most widely watched events in the world. Football today "is an economically significant, highly popular, globally networked cultural form" (Smart 2007:6), it is an integral part of the consumer culture and is focused on celebrities. Sports stars are elevated to an iconic global celebrity status, but still represent local and/ or national communities.

Most celebrity players I interviewed had only attended elementary school, around $15 \%$ had been able to finish high school, one had entered university (he dropped out when he moved abroad), and only one had studied at a university level. Their wives generally had higher schooling than the players, although only three of them had had a univesity education.

5 The ethnographic data was gathered mainly in Seville, Spain (where I lived for two months in 2003 and one in 2004), and Eindhoven, Holland (which I visited several times between 2004 and 2008). The contacts were also conducted in Canada (Toronto); the Netherlands (Almelo, Groningen, Alkmaar, Rotterdam, and Amsterdam); Japan (Tokyo); France (Lyon, Le Mans, Nancy and Lille); Monaco; Belgium (Charleroi); Greece (Athens); Korea (Seoul); Morocco (Marrakesh); Uruguay (Montevideo); and Brazil (Fortaleza, Salvador and Belem) between 2003 and 2012.

6 Elias and Dunning (1986) call sportization the transformation of games by the adoption of rules, outside referees, competitiveness etc. which characterize modern sports. 
Becoming a pastor now appears to be an increasingly frequent option when footballers retires from playing. For instance, another former member of the Brazilian national team, Müller, became a pastor after leaving soccer, and Kaká has also expressed his desire to become an Evangelical pastor,7 not a coach, team executive or commentator.

They may organize Bible reading groups among players, open (or plan to) churches, and wish to be preachers in the after-football future to support their neo-Pentecostal denominations. However, these activities seem negligible compared to the impact of the religious messages they propagate in the media and the size of their donations. As we know (Oro 2005/2006:320), "Brazilian" neo-Pentecostal denominations are disseminated among the Brazilian diasporic communities and largely, but not exclusively, through mediascapes (Appadurai 1990:9). ${ }^{8}$ For instance, during my fieldwork I noticed that players in Spain, Holland, France, Japan, Canada and Morocco watched Brazil's Record television network every day. Present in over $80^{9}$ countries, Record is a powerful channel for the dissemination of the precepts of the Universal Church of the Kingdom of God (UCKG). Along with the Women's Network (Rede Mulher) and the 71 radio stations in Brazil that also belong to the UCKG, Record helps consolidate a community of believers that in 2000 surpassed two million people (Oro 2005/2006: 324).

Since football is the most-watched television programing in the world, the Brazilian players on the national squad and Brazilian players living abroad have had an important role in the dissemination of neo-Pentecostalism, acting as global "pastors." Even though the Fédération Internationale de Football Association (FIFA) prohibits religious (or ideological) propaganda, ${ }^{10}$

7 “'I would very much like [to be a pastor], but it would be a long journey. It is necessary to study theology, take a course, go deep into Bible study, into Evangelicalism'. In: “Kaká said that he was a virgin when he got married and intends to be a pastor," Folha on-line, 17/12.2007, accessed on October 6, 2012, at http://www1.folha.uol.com.br/folha/esporte/ult92u355651.shtml

8 Mediascape refers to the capabilities to produce and disseminate information and images of the world, in global cultural flows, using electronic media.

9 http://noticiasdaigrejanomundo.blogspot.com/; accessed on April 2011.

10 "Players must not reveal undergarments displaying slogans or advertising. The basic compulsory equipment must not have any political, religious or personal statements. A player removing his jersey or shirt to reveal slogans or advertising will be sanctioned by the competition organiser. The team of a player whose basic compulsory equipment has political, religious or personal slogans or statements will be sanctioned by the competition organiser or by FIFA" http:/www.fifa.com/aboutfifa/documentlibrary/ doclists/laws.html\#laws; accessed on October 21, 2012. 
it has been visible in a number of ways since the 1970 World Cup. ${ }^{11}$ In fact, one image stands out from the many photos of Brazil's victory in the 1994 World Cup: that of a circle formed by players and the technical staff of the Brazilian team, in a group hug, praying at the center of the Rose Bowl in Pasadena, in the United States. The scene was repeated with even greater intensity during the 2002 World Cup, with the players kneeling at the center of the field of the International Stadium in Japan. The image transmitted to the largest global television audience in history, promoted Brazilian faith worldwide and established itself as a visual topos repeated each time the Brazilian team won a tournament. This evolution underlines a shift in Brazilian football from its original association with the nation (through flags, national anthems etc.) to an equally strong association with evangelical religion.

This was visible at the commemoration of the Brazilian team's victory during the Confederations Cup of 2009 in Johannesburg, South Africa. ${ }^{12}$ Once again the scene was repeated of the players and technical staff kneeling in a circle on the pitch in prayer. Moreover, most of the players wore a white shirt that read I belong to Jesus, in English, to reach a larger audience. When they reached the podium to receive their trophies, and were told that they could not wear these shirts, they took them off, taking care to carry them in a visible way. Some held them in their hands, and Lúcio, the captain, placed it on his shorts in such a way that the words I love Jesus were visible when he raised the Cup. The message was thus broadcast worldwide on TV-I was watching the scene in Athens, Greece. News reports about the return of the Brazilian delegation from South Africa written by reporters who shared the 'plane said the flight was peaceful, serene, and nearly silent, quite different from the party atmosphere, or the samba and dancing that were common after other Brazilian victories. The transition from a party mood to a more peaceful atmosphere appears to reflect a transformation in the ethos of the national team: the new religious hegemony is expressed in the players' behavior.

In the four years between their victory in the Confederations Cup of 2005

\footnotetext{
11 At the time, it issued a note of clarification that there was no punishment because the acts of faith took place after the game. The first time was probably after a goal by Petras, from the former Czechoslovakia team against Brazil in the 1970 World Cup, which was commemorated by the player on his knees, in a gesture that was repeated by the Brazilian star Jairzinho a few games later.

12 Football does not have a monopoly on these expressions of gratitude. Similar scenes are observed at U.S. football games. For example, at "Super Bowl XLI (2007) coaches of both teams had established public reputations as Christian gentleman. The next Super Bowl brought more of the same". Hoffman 2010:5.
} 
and 2009, the Brazilian squad exchanged a "partying" ("bad-boy") captain, Ronaldinho Gaucho, for a neo-Pentecostal one, Lúcio. It went from a group of players who prayed after victories, but celebrated more intensely by dancing with pandeiros (tambourines) and atabaques (drums), to one that may still samba, but is more likely to be found praying and listening to gospel on their headphones. ${ }^{13}$ At least one of these percussion instruments is not religiousneutral: although present in secular contexts, atabaques are largely used in Afro-Brazilian religious rituals (Carvalho 1984, Ferreti 1985, Lody \& Sá 1997) and are avoided in Pentecostal ones. Pandeiros, even if not used in religious rituals, are connected with another African-Brazilian cultural expression since they are largely used in capoeira along with berimbaus (a single-string percussion instrument) and atabaques. There is nothing innocent in the presence or absence of these instruments because a repulsion towards AfroBrazilian cults, which are considered diabolic, is central to neo-Pentacostalism. It is up to the believers to keep the Devil at a distance.

For years, prayers, pagode and samba music co-existed within the national team with no apparent conflict. Although they continue to co-exist, the celebrations of 2009 clearly attest to the new hegemony of religion over samba. While Ronaldinho put down the tambourine to raise his trophy, Lúcio lifted his I Love Jesus shirt in a gesture that has great significance in the football liturgy. To be sure, religious propaganda was not absent in 2005. In the photos of that event, Lúcio and six other Brazilian players appeared with shirts praising Jesus, but they were behind the stage where the players received the trophy, and the images were dominated by the pagode musical celebration commanded by Ronaldinho (the player voted the best in the world that year) and his wide grin. Music and dance prevailed in the televised images and photos. The team led by the Brazilian coach Dunga from 2006 to 2010 was the first clearly to place neo-Pentecostal religion at the center of its group manifestations. While in 1994, Captain Dunga raised the Cup while cursing the press, and in 2002, Capitain Cafu did so expressing his love for his poor, home neighborhood and his wife, ${ }^{14}$ it is very probable that Jesus would once again have been praised by Lúcio, had Brazil won the 2010

13 Brazilian footballers contacted during the study also played Brazilian religious music in their cars. 14 His tee-shirt read "100\% Jardim Irene" (referring to his neighborhood) and he said "Regina, eu te amo” [Regina, I Love you]. 
World Cup. The television cameras and the photographic images would thus be transmitting a faith that through football conquers a formidable and astounding planetary stage. In this sense, more than being Dunga's team, it was that of the assistant coach Jorginho, who played on the team that won the 1994 World Cup, and for many years in Germany for Bayer Leverkusen and for Bayer of Munich and who is the neo-Pentecostal founder of the church in Munich's central square.

In addition to bringing along their religious practices, attending Evangelical churches abroad along with other Brazilian immigrants and, in some cases, establishing their own temples, Brazilian players have significantly contributed to the promotion of neo-Pentecostalism in the media, or, at least, of the words "Jesus" and "God." These symbolic gestures propagated in the mediascape promote their religious beliefs on a global scale, in a sort of "banal religiosity" if we can borrow from the term "banal nationalism" coined by Billig (1995) to qualify, in his case, subtle or indirect expressions of nationalistic sentiments, which nevertheless are vital in the reproduction of nationalism. Michael Billig (1995:6) distinguished "nationalism" from 'banal nationalism." Both cover "the ideological means by which nation-states are reproduced." But "there is a distinction between the flag waved by Serbian ethnic cleansers and that hanging unobtrusively outside the U.S. post office." Banal nationalism is a term he created to "cover the ideological habits that enable the nations of the West to be reproduced," daily, in the lives of its citizenry. ${ }^{15}$ Sports, through mediascapes, play an important role to remind readers and viewers daily what nation they belong to, and doing so "they can be seen as banal rehearsals for the extraordinary time of crises, when the state calls upon citizenry, and especially its male citizenry, to make ultimate sacrifices in the cause of nationhood" (1995:11).

In the case of the Brazilian players, propagating neo-Pentecostal religion in the stadiums, away from temples, preachers and Bibles, is a powerful (and yet banal) form of neo-Pentecostal propaganda.

Popular Catholicism and the Afro-Brazilian cults (macumba) had always been (Rosenfeld 1993) and continue to be present in Brazilian football. Like

15 Banal, as Billig explains by referring to Arendt (1999), is not synonymous with harmless or innocuous, since nationalism can express itself in more violent forms, such as wars. 
the flag "hanging unnoticed on the public building," 6 the constant references to God in their interviews, the gestures of thanksgiving and sacred words on T-shirts constantly remind fans in the stadiums and larger television audiences of the importance of God. Raising their hands to the sky in celebration of a goal (a gesture Brazilian goalkeeper Taffarel made in 1994, which has been imitated by Kaká and many other players), kneeling after a goal or saying a blessing after barely missing a goal - a gesture that Romário made famous (Rial 2003), are also common. In addition to these expressions of gratitude, it is common for Brazilian players to enter the pitch with their right foot first while making a blessing, and then raise their arms to the sky moments before the match begins. Goalkeepers, meanwhile, may kick the posts and touch the crossbar while saying a blessing and asking for protection.17 These gestures are expressions of various forms of popular religiousity in Brazil, including Afro-Brazilian religions. They are forms of asking for "protection" also indicated by the sign of the cross and the common use of sentences that begin or end with "God willing" or "Thank God". Other statements, often found on their T-shirts, indicate the recent adhesion to neoPentecostalism: ("Gott is meine Kraft" [God is my strength], "Danke Jesus" [Thank you Jesus]) 18. These gestures and statements escape FIFA's strict controls designed to prohibit religious propaganda from silently infiltrating the daily lives of millions of viewers via television.

The presence of these Brazilian players on every continent and their central role in the clubs where they perform, make them important channels in the dissemination of religious sentiment. Of course, the players are not the only channel. Even when a television program is transmitted to over 150 countries, we are still dealing with explicit religious rituals. The potential power to transmit religious words and gestures during football matches lies exactly in their semi-visibility, in their diffusion in the background i.e., banal religiosity. Perhaps, we could say we are facing a new deterritorialization of religious beliefs, in relation to which the media act as a tool in both direct and in more banal, mundane ways - like the display of religious

16 "The metonymic image of banal nationalism is not a flag which is being consciously waved with fervent passion; it is the flag hanging unnoticed on the public building" (Billig 1995:8).

17 Christianity no longer holds a monopoly on relations with the divine in football. Recently, players have appeared kneeling in a Muslim position upon celebrating a goal.

18 I would like to thank Peter Fry for these references. 
slogans on players' T-shirts or their making of the sign of the cross upon taking the field or after scoring a goal. For this powerful involvement of the players to become possible, profound changes had to be made in Evangelical religions.

\section{Prosperous Athletes of Christ}

The adhesion of football millionaires to neo-Pentecostalism (and of other players who are not millionaires and have lifestyles similar to economic migrants in the Brazilian diaspora) coincides with two "reforms": the adoption by Brazilian Pentecostal churches of the Theology of Prosperity in the 1970s (Mariano 2010); and the rapid professionalization of Brazilian football, in the second globalization phase. Until then, Brazilian Pentecostal followers, who call themselves crentes (believers), were known for their adoption of rigid behavioral norms. They were prohibited from enjoying pleasures in this life, such as drinking alcohol, listening to music other than that during religious service, watching television and having sex before marriage. Sports and gambling were among the prohibited activities, the soccer ball was known as the "devils egg." The Theology of Prosperity preached, however, that the faithful had the right to enjoy their happiness on Earth, and that they could and should seek financial success and enjoy it. They aggregated principles of self-help and mental control ("positive thinking") to their Biblical preaching. This sparked ethical changes among the faithful, who were now free to express themselves through consumer goods, music and sports and integrate these pleasures into their lifestyle. This also started an aesthetic revolution, as women could cut their hair short, wear jeans, etc. The Theology of Prosperity had such a strong repercussion that scholars argued it formed a third wave of Pentecostalism and constituted what is known as Brazilian neo-Pentecostal congregations.

It is noteworthy, however, that the first explicit association between football and neo-Pentecostalism took place through the Atletas de Cristo [Athletes for Christ] movement, which rejected the Theology of Prosperity. As Nunes (2003) reports, the movement was created in Belo Horizonte in 1978 by a pastor and João Leite, a goalkeeper from the Atlético Mineiro football club. He sought to include athletes from different sports, but it was football that gained the most visibility. After this initial impulse, players were transformed 
into Evangelical messengers. Although João Leite insists that the movement is neither a sect, a church, or a labor union, has no political affiliations and doesn't impose rules of conduct, its founders did have ties to the Baptist Church (Nunes 2003). The movement enjoyed popularity among players from some large Brazilian clubs, where groups of Atletas de Cristo were established, and even among members of the Brazilian national team. A Brazilian team of Atletas de Cristo, composed of former players from the Brazilian national team, now plays matches to spread the Evangelical message. ${ }^{19}$ Although Athletes of Christ remains a reference, other denominations gained the preference of the players, such as the Snowball Church, which was founded by a former drug addict who became an Evangelical after contracting hepatitis in 1992, and who still surfs at weekends. Snowball targets young people with its informal rituals that incorporate rock and reggae music, Bibles with images of extreme sports on the cover, and a party atmosphere in their temples.

\section{The Protestant Ethic and the Spirit of playing football}

This association between sport and religion, is, however, much older. To better understand the context of this association, in the following paragraphs I follow Putney (2001) in his account of "muscular Christianity."

The origins of "muscular Christianity" can be traced to the New Testament, which calls for virile force (Mark 11:15) and physical health (1 Cor. 6:19-20, 9:24-27). ${ }^{20}$ Although its characteristics can be identified in the first

19 Formed by Jorginho, Silas, Tafarel, Paulo Cruz, Giovanni, Paulo Sérgio, Silvio, Axel, Paulinho Kobayashi, Deivid, Cléber Lima, Zé Carlos, Pereira, Guilherme, Daniel, Fábio Freitas and the coach Ricardo Ximenes. At: http://www.overbo.com.br/selecao-brasileira-de-futebol-atletas-de-cristo-visita-o-amapaem-marco/; accessed on 21 October 2012.

20 Mark 11-15: When they arrived back in Jerusalem, Jesus entered the Temple and began to drive out the people buying and selling animals for sacrifices. He knocked over the tables of the money changers and the chairs of those selling doves. At: http://bible.cc/mark/11-15.htm ; accessed on on October 21, 2012. 1 Cor. 6:19-20, 19 You surely know that your body is a temple where the Holy Spirit lives. The Spirit is in you and is a gift from God. You are no longer your own. 20 God paid a great price for you. So use you're your body to honor God. At: http://www.biblegateway.com/passage/?search=1+Corinthians+6\%3A19$20 \% 2 \mathrm{C} 1+$ Corinthians $+6 \% 3 \mathrm{Ag}$ \& version=CEV , accessed on October 21, 2012.

1 Cor. 9:24-27 24 Do you not know that in a race all the runners run, but only one gets the prize? Run in such a way as to get the prize. 25 Everyone who competes in the games goes into strict training. They do it to get a crown that will not last forever, but we do it to get a crown that will last forever. 26 Therefore I do not run like someone running aimlessly; I do not fight like a boxer beating the air. 27 No, I strike a blow to my body and make it my slave so that after I have preached to others, I myself will not be disqualified for the prize. At: http://www.biblegateway.com/passage/?search=1\%20Corinthians+9\&version=NIV, accessed 
centuries of Christianity, what came to be called muscular Christianity was not always an important element. The Catholic Church praised health and virility, but was more concerned with obtaining salvation, and preached that this could be achieved even if people were not healthy. A disdain for physical activities reigned in the Church for centuries, only to be contested consistently in the 19th and 2oth centuries by Protestant ministers in England and the United States who preached their conviction that men could not claim to be truly Christian if they were not "muscular Christians."

The expression "muscular Christianity" first appeared in English in 1857, in a novel by Charles Kingsley. One year later, it was used once again in another novel, by his friend, Thomas Hughes, to describe life at Rugby school. The press came to call him (and Thomas Hughes) muscular-Christian writers and also applied this label to the genre of their books: adventure novels full of Christian principles and virile heroes.

Hughes and Kingsley were not only novelists, they were also social critics who warned of the danger of asceticism and feminization as factors that weakened the Anglican Church. Before the American Civil War, they exported to America their campaign in support of greater health and virility in religion, ideas that were not immediately well accepted due to the longtime Protestant opposition to games and sport, which were activities present in festivals of the Catholic Church (Baker 2007). In fact, the opposition to muscular Christianity in America never completely disappeared. But it became weaker after the Civil War, when changes in U.S. society placed health and virility at the center of concern of many white Anglo-Saxon Protestants who saw sedentary work in offices - increasingly present in a society under accelerated urbanization - as a threat not only to health and masculinity, but also to their socially privileged positions.

Muscular Christianity was thus defined as a Christian commitment to health and virility. Its defenders promoted an "arduous life," complete with athleticism and aggressive male behavior. They called for their churches to abandon principles of a Protestantism they considered "feminine" and unsupportable. For them, a feminine influence in the church led to an excess of sentimental hymns, an effeminate clergy and sickly sweet images of Jesus. As proof that there was a "dangerous woman" in U.S. Protestant churches, 
they pointed to a supposed imbalance in the presence of men and women in the churches. "Real men" were repelled and would only return to the church when "feminized" Protestantism gave way to a muscular Christianity, a tough religion, in keeping with an arduous life.

Thus, as Putney (2001) shows, the union between Christianity and sport was stimulated by a complex amalgam of anxieties around the decline of the virility of middle class Anglo-Saxon men, given their recent engagement in activities that involved less physical effort, fear of increasing juvenile delinquency and a certain anguish caused by the growing feminist movement. These ideas that a feminization of masculine bodies was taking place, contributed to the creation of a plethora of organizations aimed at the reconfiguration of U.S. masculinity, including the Young Men's Christian Association (YMCA) (Macleod 1983). In this way, since the 1880s, Puritan suspicions about the use of the body and leisure practices were rejected and substituted with a belief in athletic training, which came to be seen as an effective form of Evangelization. As the Christian educator Lilburn Merrill summarized, boys "pray more easily and effectively running than kneeling" (Putney 2001:123).

The notion that sports can function like a religion is no longer controversial (Higgs 1995, Putney 2001, Baker 2007, Hoffman 2010). Football and religion clearly have a close relationship and it would not be an exaggeration to say that contemporary football is often the stage for the world's most widely watched religious performances:

In fact, football has procedures that are similar to those of a church: its protagonists have a rigid hierarchy; there are conventions and taboos; its special moment, the game, is held in a closed space, where there is a field, equivalent to the altar; it has a specific language and its calendar is somewhat liturgical; there is a moment of retreat, the concentration, which excludes the opposite sex, and a final result, which can lead to an examination of the conscience if there was a mistake, followed by contrition, or a moment of compensation and glory, for some, eternal, as Pelé would say. (Alvarez 2010).

However, we must be careful not to reduce one thing to another. Da Matta (2003) made a pertinent critique of the affirmation that sport is a type of religion by Michael Novak, author of The Joy of Sports (1976). As Da Matta soundly argues, the reduction of one social dimension to another does not resolve the problem. 
Magic has already been reduced to a primitive science; rituals were seen as neurotic repetitions or as expressions of mysticism; kinship ties and terms were interpreted in their matrixes of "blood" and Sport was seen as sublimation for aggressive and bellicose impulses, in the same way that Novak sees them as a modality of religion. But this does not resolve the problem, because the task remains of explaining the social dimension to which the activity in focus was reduced. If Sport can be reduced to religion, as Novak suggests, we now have to ask, what is religion? (Da Matta 2003:21)

Da Matta's observation is appropriate and clarifies this point: football is above all a ludic and anti-utilitarian activity, although it is strongly influenced by economic and political interests. It does not need to be transformed into an activity that substitutes war, as Elias proposes (1986), or into religion to merit academic or artistic reflection. Such a perspective does not imply, however, the complete absence of religion (and even of magic) in some of its practices, whether those of fans, or players.

Perhaps it would be most suitable to say that football (especially but not exclusively South American) and religion are easily and advantageously related to one other. I found religious symbols in locker rooms I visited in different places in the world: altars, images of Christ and especially of the Virgin Mary, at times simply stuck to the white tiles in heterogeneous compositions that revealed the multitude of their origins. For instance, there were serene images of the Virgin Mary, as on the pitch of the Payssandú club, in Belém, in northern Brazil, and cruel images of Christ, bleeding under a crown of thorns, as in the locker room at the Sanches Pijuan stadium in Seville, in southern Spain. I found one expression of this association that startled me in a visit one afternoon to Madrid's Vicente Calderón stadium. I thought I had entered a museum, like those that now exist in nearly all of the world's big clubs - spaces impregnated with the sacred, where visitors come to worship the objects exhibited whose auras (Benjamin 1987) stir much more intense emotions than the art in our traditional museums. But the stadium also housed the Memorial del Atlético Madrid, a space where the members and fans of the club could leave their ashes in small urns nestled in a space in one of the tiles that compose large mosaics with photos of the club and its emblem. This is nothing less than a cemetery installed in a broad and modern space inside the stadium, with a chapel to conduct funeral services. This was the solution found to respond to the many requests from fans to have their ashes 
strewn on the stadium's field, given that European law has prohibited such practices for alleged health reasons.$^{21}$ Fans have legitimated their desire to be placed here as a way to prolong their passion for football beyond life.

More than clergy of a new planetary religion, certain players rise to a sacred condition in the form of posters that populate the walls of bars and the bedrooms of youngsters throughout the world. "God lives in Catalonia," was the headline of L'Equipe, France's most traditional sports newspapers. It was praising the performance of Barcelona forward Lionel Messi the Argentine who has been elected the world's greatest player three times. The consecration of Messi was echoed worldwide and the lay terminology of praise ("genius" or "ace") was exceeded only by the religious metaphors ("God" or "extra-terrestrial") in various newspapers, including the highbrow The Times of London. Anyone who has seen all the fans in the Camp Nou stadium greet Messi with open arms, rocking back and forth and issuing a thundering "Mééééésiiiiii, Mééééésiii," cannot fail to think that the multitude can only be bowing down before someone they think to be divine. This is a "god" stimulated by the forces of his time, which disseminate his image to all corners of the planet, as they did with others before him: Pelé, Di Stefano, Ronaldo, Ronaldinho. These others, however, do not enjoy the phonetic coincidence of their name: stores and shops in Barcelona now sell a football shirt that reads: "I saw the Messiah play", with an image of the football star, his arms raised to the skies, circled by a golden aura.

This is a "Messiah" without a church, except for that located in the mediascape, that transnational space that redefines the geography of the sacred. Another Argentine player, in his time and at least in his country, received this level of consecration and even more with the founding of the Maradonist Church, in which the identities of Maradona and Argentina become fused and deified. Founded playfully in 1998 by a group of fans who began to

21 Created in 2009, the memorial already holds the ashes of about 150 fans, most of them men (20\% are women) - who do not rest there for eternity, because the contracted time of permanence is 25 years - for which 1,50o euros were paid. Many left this wish in their wills, along with the needed funds. According to the person responsible for the memorial, Ana, the visits are more intense on special days, such as All Saints Day, but occur throughout the year. One of the rooms in the memorial "serves at times as a chapel": it is a place for prayer, with chairs, a pulpit and a high table that recalls a Christian altar. If the families want, or if it has been requested in a will, she conducts a brief ceremony that may or may not have prayers, music - such as the club hymn- or another mode of performance that may have been requested. The Argentine Club Boca Juniors also has its own cemetery, but it is located in a suburb of the city. 
celebrate Christmas on Maradona's birthday, it now has some 200,000 fans, its own 10 commandments, prayers and rituals of veneration to his goals. They worship in particular the goal against England in the 1986 World Cup. Scored with his hand, Maradona himself considered it to be a divine intervention in a game marked by the memory of Argentina's tragic defeat four years earlier in the Guerra de las Malvinas (as it is known in Argentina, or the Falklands War as it is known in England). Maradona's number, diez (10) in Spanish, and the word Dios (God in Spanish) also have a phonetic proximity that helps sustain the myth.

While it is not difficult to understand how football and its heroes acquire heroic and even sacred status, what interests me here are other question: what is that makes these practices at once desirable and even mandatory? I'm interested in recognizing, as suggested by Talal Asad (1993), the materiality of certain practices, more than pursuing whether or not they are "sacred", as we know since Durkheim (1968) they can all be sacred. The point that I would like to make is that, football, through its most important protagonists, enjoys planetary veneration, probably greater than that of any religion. ${ }^{22}$ and that the Brazilian neo-Pentecostal athletes are so aware of this that they use football as a platform to disseminate their religious beliefs through a proselytism that is partially expressed in words and gestures; global pastors of what I have called a banal religiosity

This takes place, as we said, without support from FIFA, the entity that controls global football, which prohibits ideological or religious propaganda. The press also prefers to report on players' sensationalist activities rather than on the commonplace activities of the faithful. What most interests journalists are the impious actions of non-religious players, the "bad-boys," as they call players who "go out at night." It is visits to the pubs of Manchester, or the nightclubs of Barcelona and Madrid, or to the funk dances in Brazilian favelas, and players' trysts with call girls or transvestites that are covered in the media, almost never the pilgrimages to Pentecostal or Catholic churches. Only in exceptional cases involving big stars do religious activities gain space in the mediascape, as with Kaká, who, when suspended from a game of the Brazilian squad, participated in the inauguration of a new temple, and

22 "For all their differences, religion and sport seem to have been made in the image of each other. Both are bathed in myth and sustained by ritual; both reward faith and patience; both thrive on passion tempered with discipline". Baker (2007:2). 
appeared on the front page of Brazil's two leading newspapers praying intensely alongside Estevam and Sonia Hernandes, the husband and wife couple who are bishops that lead the neo-Pentecostal church Igreja Renascer em Cristo. ${ }^{23}$ Based on the news reports, in which Kaká was an exception, I expected to find "bad boys" when I initiated my contacts with Brazilian players who had emigrated abroad. Not that I did not find them, I did. But what surprised me was the overwhelming number of "good boys".

Wages are not the main concern of these athletes and their high salaries did not radically change their consumptions habits, friends or religious practices. Indeed, what amazed me most, was the large number of football players who read the Bible daily, attended religious services in neo-Pentecostal temples, and at home prayed and met with fellow players, family members and other Brazilians living abroad, even traveling to other cities to participate in religious services. With surprising consistency, interviews suggested these practices to be quite common, even among players of different social origins and educational levels (Rial 2008). Let's look more closely at some of the players' statements, beginning with Ricardo Oliveira, a globally recognized striker (Poruguesa, Santos, Real Bétis, Milan, São Paulo, Real Zaragoza and, in 2012 Al Jazira). Ricardo met his wife Débora Oliveira at a church when she was 14 years old. When I spoke with him in Seville, in 2004, Ricardo had already played for the Brazilian national team, was the leading scorer in the Spanish tournament where he played for Bétis, and was being courted by a number of large European clubs. He lived with his wife Débora who was 17 and their 8-month-old son, Anthony Richards, in a two-story house in Simon Verde, a luxury condominium in the city, and drove a BMW with leather seats and impeccable white carpets. He was extremely polite with me at all our meetings, acting as a mediator with the other players, displaying a generosity clearly related to the notion of "helping someone." Ricardo repeatedly told me how important his relationship with Evangelical followers was to his life.

23 Kakás relations with this church have gained extensive media coverage. In 2007 , he displayed the FIFA trophy he won as the world's best player at the church headquarters, and defended the bishop couple (whom he calls the "apostle and the bishop") when they were arrested and condemned to 140 days of house arrest in the United States for money laundering and conspiracy. Kaká was shown consulting the church's websites during the 2006 World Cup. A video available on the Internet (http://www.youtube. com/watch?v=loRDfI-6Lqc, accessed on October 21) shows the moment when he was anointed a priest "Presbyterian" in the United States and reveals financial details of his sale to the Real Madrid club saying that his career success "is a conquest of the apostolic people." 
His entrance into the church was seen as a watershed marked by a "commitment to God." Ricardo, like other players, described his life as being divided by a before in the kingdom of evil, and after when they entered the kingdom of God. In the before, these players "messed up," drank, took drugs (not Ricardo's case) went out with lots of women (this was not usually discussed with me because I am a woman, but I could infer it by their way of not mentioning it), and as studies show, could be violent at home. In the after ("when I came to know the Word ${ }^{24 ")}$ there was self-improvement, not in the sense of having more money or being famous, but in a more spiritual and broader sense of "being a good person." Ricardo Oliveira told me that it was thanks to this "commitment to God" that he was able to succeed as a football player.

If the player was not born into an Evangelical family, the conversion to the church would usually take place through friendship with other Evangelicals. Sometimes a future wife is religious and converts the player, although it is more common for the player to emulate the behavior of Evangelical teammates. Thus, conversions took place much more through the caring behavior of people who were admired than through proselytism. Ricardo Oliveira, told me, with tears in his eyes:

It was at Portuguesa. There I was with many Evangelicals: Sandro, Simão, Sandro Fonseca, Cafu, Evandro, Élson, Tinho. When I was with them, I saw how they were, the way they cared for me. It was a very strong example, and this made me think "wow, the Evangelicals are different." One day I was with the team in the hotel, on the eve of a game, and I saw on TV a fire in the neighborhood where my brother lives. I saw my brother, I saw the people I knew, I began to cry. And when I turned to my side, my friend was crying with me. And I asked myself "why is he crying? He doesn't even know me well, he doesn't know these people." It was a strong example, sharing sadness with a companion. (He said to me:): “Tell me, maybe I can help." He saw me crying at that moment, he began to feel, in a way, the sadness that I was feeling. This example of companionship transformed my life.

It is not so much the religion, but the "Word of God" that is important, as if the reading of the Bible were capable of establishing a direct dialog between two beings, one human, another divine. For them, the Bible is a

24 "Word" is often used as a synonym for the Bible. 
support; it assists in establishing a conversation with a friend. "God is a friend who is always with me," declared Edu (São Paulo, Celta de Vigo, Real Bétis, Internacional, Vitória and Colorado Rapids). Ricardo says that one must do the right thing to "please God," in order not to "make God sad." God, in return, "concedes these privileges that I can enjoy today." Both among the players from the global clubs as well as those from smaller clubs, I found those who considered the Bible, God and prayer to be great allies. This was the case of Jefferson Luis Escher, a player on the Kawba Atletic Club of Marrakech, today at Wydad Casablanca. We spoke in a taxi - he didn't have a car - that took us to the club apartment, where we met his wife and one-yearold child who had just arrived from Paraná, Brazil.

I say that I am Catholic, but it is more the Bible, the word that the Bible gives me. It helps a lot. It gives me strength not to be so lonely, not to be worried so much with what will happen later. It gives me security, I feel very good. Reading makes me much stronger.

He said that the Bible was his most important support to withstand the loneliness of being away from his wife and son for one year. Jeferson did not convert; he adopted the Pentecostal practice of Bible reading, and the accompanying ethics, in a more individual and autonomous way.

Ricardo, a key contact, arranged for Denilson (a TV sports commentator in 2012) and Marcos Assunçao (at Palmeiras in 2012) to meet with me. What was to be a quick encounter wound up lasting hours sitting round an improvised table at the Betis training center until we were kicked out by club security. Denilson, who is Evangelical, and Assunção, who is Catholic, also said that God was very important in their lives.

Denilson : I'm more religious (than Assunção). I'm Evangelical, a believer.

Assunção: I accept anything; if you invite me to go to church I'll go. [laughter] You can't argue over taste and religion. Each one has his own taste and religion, we have to have respect. I'm a Catholic and you're a believer

Denilson: The importance of God. I think nothing happens by accident and everything has an answer: this answer can only be given by God. I pray all the time. Because there is evil, and if you don't pray, evil will take hold of you. I pray all the time, I ask for things, neither too much nor too little. It's like a 
struggle, you know, between good and evil.

Assunção: I try to thank Him for everything He gave me. Thanks to Him I have a good life, even though I'm not [religious].

The statement of the Evangelical Denilson reveals more rigid religious practices and displays two essential points in the theology of the neo-Pentecostal denominations: the struggle between good and evil and the permanent negotiation between the individual and God ("I ask for things"). Their statements are similar to many others that I heard:

Adriano (Seville, the Brazilian national team, at Barcelona in 2012): In Brazil, we would meet the day before the matches to sing hymns, read the Bible and use the Word. On the day of the match we would pray before taking the field. Here, we don't, because here most of them are not religious, so it's a little harder. But I think we can't judge the others, each person has his own religion and we have to respect it. It's like the Bible says, "God gave everyone free will, so we are free to do whatever we want." So who am I to judge?

Alex (PSV, the Brazilian national team, Chelsea, at PSG in 2012): For me it's (God) super important. I got to know it when I was 14 at an aunt's birthday. My mom invited me to the church, and I liked it. To me God is what gives strength to my life. He has put me here, and I thank God every day for his support, his help to get here. But it's not enough to rely on God; one has to struggle.

Dill (Bahia, has played in France and Switzerland, at FC da Foz in 2012): I've converted. I've been an Evangelical since 1996, since my marriage. You ask me if I'm religious, and what I think is that God doesn't like religion. He likes you to give yourself wholeheartedly. So, regardless of religion, I think the important thing is that we search for God. God is the touchstone, the basis of everything in our life. That's what I think, and we always have meetings here at Bahia [his club]: myself, Neto, Luciano, those who are Christians. Now Marcelinho has arrived, who's also a Christian [neo-Pentecostal].

"Belief," as the players say, is seen as an indispensible support to withstand the difficulties of a career and survive the "sacrifices" of living abroad. This is the importance of the Word. We find it in players' appeals to a greater force for "protection". Prayers in the locker rooms and the asking for a blessing upon entering the pitch are indications of this significance. We can also 
find it in the thanks offered for "gifts" -- the arms raised to the sky after goals, the group prayers conducted after victories. Aren't these appeals to a greater force similar to the situation of the hunter that Mauss (1934) describes in his classic study "Techniques of the Body." In one passage, in which he relates corporal practices to magic rites, Mauss reports that a hunter was able to remain in a tree for many hours, and that the strength and resistance to pain needed to conduct this vigil came from reciting magical chants. In another, when analyzing the super- human ability of Australians near Adelaide to run with kangaroos and wild dogs, he also attributes this competence, as well as that of grabbing an opossum out of a tree, to the fact that the hunters endlessly chant a magic formula. ${ }^{25}$

Football players appear to find in prayer and in their practices of a religious character the extra strength that helps them to make or defend against a goal, or that pushes them beyond their bodily limits. It is for this reason that they touch the grass with the hand, or enter the pitch with the right foot, and kick the goal posts, in addition to more explicit gestures such as raising one's arms to the sky or making the sign of the cross before the opening whistle. These ritual acts are conducted in the hope of achieving a true material effectiveness, whether that of protecting against possible injury, of preventing the ball from passing a limit designated by a magic gesture, or, on the contrary, causing it to enter the goal. If the ritual element in football is important for the search for protection, it also has importance for giving thanks, as a counter-gift (Mauss 1990), a reciprocal exchange.

Many of these practices predate the presence of neo-Pentecostalism in football, and relate to formulas for protection, which are present both in popular Catholicism and in Afro-Brazilian religions. In recent years these practices have been joined by others from the neo-Pentecostal universe. Or, as Alex (a defender on the Brazilian national team, who was playing for PSG in France in 2012) put it, "it's not enough to rely on God; one has to struggle," one has to work hard at the club. Belief in God has a fundamental role

25 "frappe-le avec la houppe de plumes d'aigle (d'initiation, etc.), frappe-le avec la ceinture, frappe-le avec le bandeau de tète, frappe-le avec le sang de la circoncision, frappe-le avec le sang du bras, frappe-le avec les menstrues de la femme, fais-le dormir, etc” Mauss (1934) 
in consolidating a righteous personal ethic, that of a disciplined, obedient, supporting man who cares about others, who "struggle." These are important characteristics in short careers in which the body is the main tool. It is especially important in the practice of a team sport where coexistence with others is prolonged, and not only when practicing the sport itself - the training and games - but in preceding moments: the long hours in "concentration" when the team is isolated in a hotel or training center, the tense waiting in the locker room, the unending hours traveling by bus, in airports and on flights. These periods away from families are generally seen as unpleasant, when not as veritable prisons even more so for players who live abroad. Thus, religion (or "faith," as they prefer) formats a particular habitus (Mauss 1968 [1934]) that allows them to deal with the experience of hypermobility that is characteristic of their careers. That is, religion (like magic as indicated by Mauss) serves as a technology to improve the performance in sport (Asad 1993; Vásquez 2011) which is professionally appropriate.

In addition, belief establishes and consolidates friendship with other Brazilian players. It provides support in an extremely competitive professional field. "The pressure comes from all sides: the club, the manager, the fans," said Ricardo, summarizing his situation in a Hobbesian environment.

The individual spark of the players is often associated to something "magic", a gift for which the players have no explanation - and which is thus closer to the universe of religions that incorporate magic and saucery in their cosmology. Nevertheless, the gift is not enough - team football today requires work and struggle for which divine help is welcome and which is offered by the neo-Pentecostal religions.

For Brazilian athletes, religion appears to act as a way to discipline the body, creating a productive worker, at the same time as it constructs a sense of community that helps to overcome a world without feelings, as did Methodism in England, as shown by E.P.Thompson in The Making of the English Working Class (1991), and as did Pentecostalism in São Paulo, as shown by Peter Fry (1978). The fact that many are inserted in more secular societies such as those of Central Europe may accentuate this trend, although this factor does not seem relevant to me, given that I found the same presence in countries like Brazil, Spain or Uruguay, which are less secular.

Mediation from preachers is rarely emphasized in these statements, with the exception of Alex. When I met him, at Eindhoven, where he played for 
PSV, Alex told me that he often went to Amsterdam to attend services of a Brazilian pastor. At times, he went in the company of the goalkeeper Gomes (Cruzeiro, the Brazilian national team, PSV, and at Tottenham in 2012), but neither Gomes nor his wife emphasized the presence of the pastor, although they mentioned it. Both took their families on a sort of pilgrimage that combined religion and tourism. According to Alex:

Most (of the believers present at the church) are Brazilian, the pastor is also Brazilian. He doesn't speak Dutch, it's all in Portuguese. We talk to people there, they're not players, but we make friends. I saw it on the website of "God is Love," it's www.deuseamor.com.br, it's from Brazil. I called and spoke to the pastor. They are also in Belgium, Switzerland, England, I always go there. To me, it's fundamental."

These churches are meeting places for Brazilian migrants, where in addition to religion, Billig's "banal nationalism”, is reaffirmed. By meeting other Brazilians of the diaspora at neo-Pentecostal churches and through talks about popular Brazilian television such as Globo's soap-operas and Record's programs, by sharing cooking recipes adapted to local ingredients, by exchanging addresses of Brazilian groceries, they also stress this nationalism. Indeed, like other Brazilian emigrants abroad, these players display their nationalism daily - the Brazilian flag that I saw used as tablecloth in the entrance hall of Gomes's (PSV/Eindhoven, at Tottenham/London in 2012 ) house is just one example. The father of André Bahia (Feyenoord of Rotterdam, at Samsunspor in 2012) once invited me to eat bobó de camarão, made possible by ingredients he found at a "Suriname market" in Amsterdam. I had rice, beans, and picadinho de carne (beef hash) at Ari's (AZ/Alkmaar, the Brazilian national team, at Spartak Moscow in 2012) with ingredients supplied by a Turkish shop in Alkmaar. In Japan, I saw a large roving lorry that shuttles between the Brazilian Embassy, Banco do Brasil (Brazil's national bank) and other spots. Brazilians were able to find on its shelves local brands such as Perdigão chicken, Phebo soap, sausage for barbequing, and even rice and Brazilian Playboy magazines. Players at Tokyo Verdy who I interviewed (Hulk ${ }^{26}$, the Brazilian national team, at Zenit/St Petersburg in 2012, Diego de Souza, at the Kyoto Sanga in 2012 and Zé Luis, Atlético Mineiro, at Paraná in 
2012) were unanimous in affirming that they would rather consume Brazilian products, and that they do have easy access to them. In the Netherlands, even a Brazilian wire wool brand (Bombril) can be purchased online, through the website Finalmente Brasil (Finally Brazil), which also offers mail orders to other European countries. Its store in Amsterdam is supplied yearly with eight containers of Brazilian products (shampoos, Minâncora ointment, pao de queijo [cheese rolls], beers, Fanta Uva grape soda, meat, etc), as the manager told me. The restaurants they go to almost every day are either Brazilian or serving food that is similar to Brazil's. Each time they visit the country, many products are brought back in their luggage, and many others are obtained through importers or brought by guests (relatives and friends).

As so many other emigrants of the Brazilian diaspora, these players and their families reinforce their Brazilianness through everyday consumption. The commodities that they regularly consume reassert their national identities. What would seem to be a cosmopolitan form of consumption that connects them to the world at large (cable TV, Internet and other electronic media) operates as an instrument of approximation with Brazil.

The same is true in regards to their choice of a church. Helinho (Toronto Lynx,), who is not Evangelical, would attend the Toronto temple to meet other Brazilians. Ricardo Oliveira and Débora went to a non-Brazilian temple, and like Gomes and Flávia, did not like its style - although for different reasons. Gomes' wife thought that the temple in Amsterdam was "too serious" in contrast with Brazilian temples, where services are "more cheerful". Ricardo Oliveira's wife thought the opposite about the temple she visited in Seville. Many players prefer to organize domestic services with other players and migrant Brazilians, as do the players of Celta de Vigo. Religious space, either in houses or churches, thus serves to reaffirm a national identity in the diaspora.

None of the players I contacted spontaneously mentioned anything about paying a tithe, and in general, avoided mentioning the delicate issue of their wages. Even so, it is quite probable that many of them are among the Evangelical churches' largest contributors. ${ }^{27}$

27 Neymar (Santos), a rising young talent is a faithful contributor to the Igreja Batista Peniel, of São Vicente, in São Paulo State Brazil. He donates $10 \%$ of everything he earns, as his father told journalist Debora Bergamasco. "His first little salary was R $\$ 450$. We signed his first contract at Santos and my wife took the R $\$ 45$ and gave it to the church each month, OK, there was still $\mathrm{R} \$ 400$ left over to pay the bills. Then he started to earn $\mathrm{R} \$ 800$. Very good, he donated $\mathrm{R} \$ 8 \mathrm{o} . .$. But God began to test, right? We got R\$ 
To conclude this section, let's return to the words in the epigraph "Make a miracle happen in me," which I heard sung by Felipe Mello, when he played for Juventus, the Italian club with the largest fan base, and who was also on the Brazilian national team. ${ }^{28}$ The song appears to include some of the maxims that allow us to understand why the neo-Pentecostal theology conforms so well to the life projects of the football players: a project of social mobility ("I want to rise/As high as I can), which involves great transformation (“Change my constitution"), marked by a highly competitive professional environment that poses constant danger of work accidents ("Heal all the wounds"), and by warnings against hedonist appeals, seen as harmful to the body - the players' principal work tool ("Teach me to be holy"). A career that can lead to such tremendous wealth is experienced as a divine prodigy ("Make a miracle happen in me").

\section{Final Considerations}

Football joins religion in a perfect matrimony of interests - everyone benefits. For the clubs, the players' Pentecostalism guarantees good tools for profit: healthy bodies and sound minds. For the players (especially neo-Pentecostal adherents), it offers a cosmology that orders their daily lives, prescribes what they should and should not do, differentiates good and bad, and thus keeps them away from the temptations of a lifestyle seen as harmful to their professional careers. In addition, the Bible readings in particular, but also attending services in temples or meetings with one another, help them to remain serene in a field of great tension and competition with other players in the clubs, having the aid of a real and active God. At the same time, as a strong stimulant of sociability and networks creation, their religion brings them into contact with people who are not necessarily also football players.

\footnotetext{
400 thousand. Caramba, oh my, how are we going to tithe R $\$ 40$ thousand? It's worth a car! Man! But then you think that God was faithful. Boom, he gives R $\$ 40$ thousand! But then came 'catapatapum' reals. My God, I don't even want to know, 'tithe' this right away (smiling). That's right... God tests you in the little and the great,' exclaims the patriarch of the Silva Santos family. And what does the player think of this (...). Does it hurt giving up R\$ 40 thousand? 'For God, nothing hurts. And I think it's good. We know the pastor at Peniel very well. I've been there for ten years and now they are expanding the church. I think that if we believe in God, things come naturally. God gave me everything: a gift, success." At: http:/| blogs.estadao.com.br/sonia-racy|'quero-um-porsche-e-uma-ferrari-na-garagem'|\#respond, accessed on October 21, 2012.
}

28 TV Program: Expresso da Bola, de Décio Lopes, 9/04/2010, Sportv. 
More than normal social routines, which evidently imply control over the body, those demanded of high-performance athletes like the football players examined here, require much stricter control of mind and body, a state of permanent vigilance and a distancing from everything that goes against the asceticism required by the profession. The Protestant ethic in its current manifestation in the Theology of Prosperity and other Evangelical practices provides a perfect framework for this order of the body and mind to occur, encouraging daily self-discipline and the conscious and constant monitoring of the individual over the body and emotions. It also favors obedience to rules - and the daily activity of this professional is permeated by them - serving as a civilizing device (Elias 1994) that promotes better insertion of individuals in modern institutions. Voluntary obedience, discipline, self-control, selfawareness and reflexivity (Giddens 1991), are some of the collateral effects that this religious ethic offers that are beneficial to their profession and integration in contemporary-modern urban societies.

Nevertheless, this asceticism must have a limit. To be able to be incorporated by millionaire players, its ideology must include access to material goods, given that the highly successful professional career is also that where the individual, in addition to achieving prestige, obtains material gains. The Theology of Prosperity provides conciliation between corporal and emotional asceticism and material consumption. Not only can practicing neo-Pentecostals demonstrate their success from a material perspective, it is imperative for them to do so. The possession of goods is proof that they have a good dialog with God. Material wealth is seen as a compensation for living a life of obedience to God. Inversely, they need to become rich to donate more money, because those who donate large sums are good people.

Finally, for those who live abroad, religion also provides a strong foundation to help them endure the sacrifice of being distant from an imagined Brazil and their families and childhood friends, as well as the nostalgia for solidarity and authenticity. It also helps affirm the national identity. The hymns that the players sing or listen to in their luxury cars speak of radical changes like those that these players experience in their daily lives, and for this reason touch an important note. They establish a dialog with a life project of social mobility where the sports victories are associated with victories in the economic sphere. They make tolerable radical transformations in a short time and in strange spaces, because even those who remain in Brazil 
usually live far from their families of origin and their childhood friends. Religion, that is, faith, offers football players extra strength and the ability to expand the limits of their bodies in endurance and strength, as Mauss has indicated. Religion acts as a tool to manage fame and fortune, which can lead to both a short football career and damnation. So, it is a kind of this-worldly asceticism without the Puritan fear of consumption, as long as consumption is properly sacralized through a Theology of Prosperity.

On the other hand, football offers religion nothing less than the largest and most important stage for its preaching, and is simultaneously capable of reaching billions of homes on the planet. It offers "selfless soldiers of the Word," missionaries who demonstrate the faith globally (through slogans on tee-shirts, tattoos, and interviews), thus disseminating banal religiosity through the mediascapes and increasing the contingent of believers. They are "soldiers of the faith", global "pastors", who also sustain it financially, tithing their millionaire earnings - when they do not themselves open a church, as entrepreneurial missionaries. Through the power of mediascape to transmit images of these players as evangelical Christian, Pentecostal denominations based in Brazil gain impetus and worldwide recognition.

\section{Bibliography}

ALVAREZ, Vera Cintia. 2010. "Política externa e futebol, ora bolas...". Revista do Brasil, 17: 80-91, "Futebol”. Brasília: Ministério das Relações Exteriores, Divisão de Divulgação Cultural.

APPADURAI, Arjun. 1990. "Disjuncture and difference in the global cultural economy”. In: M. Featherstone (ed.), Global culture. London: Sage. pp. 295-310. ARENDT, Hannah. 1999. Eichmman em Jerusalém: um relato sobre a banalidade do mal. São Paulo: Companhia das Letras.

ASAD, Talal. 1993. Genealogies of religion: discipline and reasons of power in Christianity and Islam. Baltimore and London: The Johns Hopkings University Press.

BAKER, William J. 2007. Playing with God: religion and modern sport. Cambridge: Harvard University.

BENJAMIN, Walter. 1987 [1936]. "A obra de arte na era de sua reprodutividade técnica”. In: Obras escolhidas: magia e técnica, arte e política. São Paulo: Brasiliense. pp. 165-197. 
BILLIG, Michael. 1995. Banal nationalism. London: Sage.

CARVALHO, José Jorge de. 1984. “Music of african origin in Brazil”. In: M. M. Fraginals (ed.), Africa in Latin America. New York: Holmes \& Meier. pp. 227-248.

DA MATTA, Roberto. 1990. Carnavais, malandros e heróis: para uma sociologia do dilema brasileiro. Rio de Janeiro: Guanabara.

DA MATTA, Roberto. 2003. "Notas sobre as imagens e representações dos Jogos Olímpicos e do futebol no Brasil". Antropolítica, 14: 17-39.

DURKHEIM, Emile. 1968 [1912]. Les formes elémentaires de la vie religieuse: le système totémique en Australie. Paris: PUF.

ELIAS, Norbert. 1994. O processo civilizador. Rio de Janeiro: Jorge Zahar Ed.

ELIAS, Norbert; DUNNING, Eric. 1986. Quest for excitement: sport and leisure in the civilizing process. Oxford: Basil Blackwell.

FERRETTI, Sergio Figueredo. 1985. Querebetan de Zonadonu. São Luís: Universidade Federal do Maranhão.

FRY, Peter. 1978. "Manchester e São Paulo: industrialização e religiosidade popular". Religião e Sociedade, 3: 25-72.

GIDDENS, Anthony. 1991. Modernity and self-identity. Self and society in the late modern age. Cambridge: Polity.

GLUCKMAN, Max. 1962. Essays on the ritual of social relations. Manchester: Manchester University Press.

HIGGS, Robert. 1995. God in the stadium: sports and religion in America. Lexington: University Press of Kentucky.

HOFFMAN, Shirl James. 2010. Good game: Christianity and the culture of sports. Waco: Baylor University Press.

HUBERT, Henri; MAUSS, Marcel. 1968 [1906]. "Introduction à l'analyse de quelques phénomènes religieux”. In: M. Mauss (ed.), Oeuvres. Paris: Editions de Minuit. pp. 3-39.

LODY, Raul. 2003. Dicionário de arte sacra \& técnicas afro-brasileiras. Rio de Janeiro: Pallas.

LODY, Raul; SÁ, Leonardo. 1987. Atabaque no candomblé bahiano. Rio de Janeiro: Funarte, Instituto Nacional do Folclore/ Instituto Nacional de Música.

LOPES, José Sergio Leite. 1996. Sucessos e contradições do futebol "multirracial" brasileiro. Rio de Janeiro: UFRJ. Mimeo.

MACLEOD, David I. 1983. Building character in the American boy: the boy scouts, 
YMCA and their forerunners, 1870-1920. Madison: University of Wisconsin Press.

MARIANO, Ricardo. 1995. Neopentecostalismo: os pentecostais estão mudando. Dissertação de Mestrado, Universidade de São Paulo - São Paulo.

MARIANO, Ricardo. 1999. Neopentecostais - sociologia do novo pentecostalismo no Brasil. São Paulo: Loyola.

MARIANO, Ricardo. 2010. “Império Universal.” Folha de São Paulo, Caderno Mais, 05/02/2010, p. 4.

MARKOVITS, Andrei; RENSMANN, Lars. 2010. Gaming the world: how sports are reshaping global politics and culture. Princeton and Oxford: Princeton University Press.

MAUSS, Marcel. 1980 [1934]. "Les techniques du corps”. In: Sociologie et anthropologie. Paris: PUF. pp. 364-385.

MAUSS, Marcel. 1968 [1909]. Oeuvres 1. Les fonctions sociales du sacré. Paris: Les Éditions de Minuit.

MAUSS, Marcel. 1973 [1922]. Essai sur le don. Forme et raison de l'échange dans les societés archaïques. Paris: PUF. pp. 149-279.

NOVAES, Regina. 1998. Novo nascimento: os evangélicos em casa, na igreja e na política. Rio de Janeiro: Mauad.

NOVAK, Michael. 1976. The joy of sports: end zones, bases, baskets, balls, and the consecration of the american spirit. New York: Basic Books.

NUNES, Francisco José. 2003. Atletas de Cristo: aproximações entre futebol e

religião. Dissertação de Mestrado do Programa de Estudos Pós-Graduados em Ciência Sociais, PUC/SP — São Paulo.

ORO, Ari Pedro. 2005/2006. “O neo-pentecostalismo macumbeiro”. Revista da USP, 68: 319-332.

PIERUCCI, Antônio Flávio; PRANDI, Reginaldo. 1996. A realidade social das religiões no Brasil. São Paulo: Hucitec.

PUTNEY, Clifford. 2001. Muscular Christianity. Manhood and sports in Protestant America, 1980-1920. Cambridge, Mass.: Harvard.

ROSENFELD, Anatol. 1993. Negro, macumba e futebol. São Paulo: Perspectiva.

RIAL, Carmen. 2003. "Futebol e mídia: a retórica televisiva e suas implicações na identidade nacional, de gênero e religiosa”. Antropolítica, 14(2): 61-8o.

RIAL, Carmen. 2008. "Rodar: a circulação dos jogadores de futebol brasileiros no exterior”. Horizontes Antropológicos, 14(30): 21-65. doi. org/10.159o/So104-71832008000200002 <http://www.scielo.br/scielo. 
php?script=sci_arttext\&pid=S0104-71832008000200002\&lng=en\&nrm=iso> SADRI, Ahmad. 1992. Max Weber's sociology of intellectuals. New York: Oxford University Press.

SMART, Barry. 2007. "Not playing around: global capitalism, modern sport and consumer culture". In: R.Giulianotti and R. Robertson (ed.). Globalization and Sport. Oxford: Blackwell Publishing. pp.6-27.

THOMPSON, E. P. 1991 [1963]. Making of the English working class. Toronto: Pinguin Books.

VALLET, Odon. 1998. “Entre politique et religion”. Le Monde Diplomatique, 39: 79-85.

VÁSQUEZ, Manuel A. 2011. More than belief: a materialist theory of religion. Oxford: Oxford University Press.

VÁSQUEZ, Manuel A. ; MAQUARDT, Marie Friedman. 2003. Globalizing the sacred: religion across the Americas. New Brunswick, New Jersey and London: Rutgers University Press.

WEBER, Max. 1951. The religion of China: confucianism and taoism. Glencoe : Free Press.

WEBER, Max. 1958. The religion of India: the sociology of hinduism and buddhism. Glencoe : Free Press.

WEBER, Max. 1996. A ética protestante e o espirito do capitalismo. Lisboa: Editorial Presença.

\section{About the author}

Carmen Rial teaches anthropology at the Federal University of Santa Catarina, is a researcher of the CNPq (National Council of Scientific and Technological Development), directs the Center for Visual Anthropology (NAVI), and is a member of the Institute of Gender Studies (IEG). She received her doctorate from Universiy of Paris V - Sorbonne. Her work focuses on cultural globalization, transnational migration, gender, consumption and sport. Rial is the co-editor of Diásporas, Mobilidades, Migrações (2011), Fronteiras de Gênero (2011), Diversidades: dimensões de gênero e sexualidade (2010).

E.mail: rial@cfh.ufsc.br

Tanslated by Jeffrey Hoff

Article received August 15, 2012, accepted for publication October 10, 2012 